\title{
DRB1*11 allele expression and HER2 pre-existing immunity may predict benefit in breast cancer patients vaccinated with the HER2 modified AE37 peptide vaccine
}

\author{
Eleftheria A Anastasopoulou ${ }^{1 *}$, Panagiotis Tzonis ${ }^{1}$, Sotirios P Fortis ${ }^{1}$, Louisa Mahaira', Christoforos Vaxevanis ${ }^{1}$, \\ Alexandros Ardavanis ${ }^{2}$, Elizabeth A Mittendorf ${ }^{3}$, George E Peoples ${ }^{4}$, Constantin N Baxevanis ${ }^{1}$, Michael Papamichail ${ }^{1}$, \\ Sonia A Perez ${ }^{1}$
}

From 30th Annual Meeting and Associated Programs of the Society for Immunotherapy of Cancer (SITC 2015) National Harbor, MD, USA. 4-8 November 2015

\section{Background}

Identification of immune biomarkers indicating potential clinical benefit from immunotherapies may contribute to the selection of the right patient for the right therapy. We have recently reported that HLA-DRB1*11 and HLA-A*24 alleles might serve as predictive factors for immunological and clinical responses to vaccination with AE37, the Ii-Key hybrid peptide of HER2 ${ }_{776-790}$ (AE36) in prostate cancer patients. The purpose of this study was to investigate the predictive significance of DRB1*11 allele expression in relation to immunological and clinical response in breast cancer patients vaccinated with AE37 in a randomized Phase II clinical trial.

\section{Methods}

This trial (ClinicalTrials.gov Identifier: NCT00524277) enrolled node-positive or high risk node-negative patients with any degree of HER2 expression (IHC 1-3+ or FISH > 1.2), rendered disease-free following standard of care therapy. Patients were randomized to receive either AE37+GM-CSF (vaccine group) or GM-CSF alone (control group) in 6 monthly intradermal primary inoculations followed by 4 boosters administered every 6 months. The current analysis includes data from 55 patients enrolled and vaccinated with AE37 in Greece, where the frequency of HLA-DRB1*11 is high. HLA-typing and measurement of TGF $\beta$ levels in serum were

${ }^{1}$ Cancer Immunology and Immunotherapy Center, Saint Savas Cancer Hospital, Athens, Greece

Full list of author information is available at the end of the article performed using Luminex ${ }^{\circledR}$ technology. Immunologic responses were assessed in vivo using the delayed-type hypersensitivity (DTH) test and in vitro with IFN- $\gamma$ ELISPOT assay.

\section{Results}

Of the 55 vaccinated pts, 31 were found to be DRB1*11+ (56\%). At baseline prior to vaccination, 22\% (12 out of $55)$ of the vaccinated patients demonstrated pre-existing immunity against AE36 by IFN- $\gamma$ release (defined as above the 75th percentile of all enrolled patients). Among patients with pre-existing AE36 immunity, the majority, $67 \%$ (8 out of 12 ), were found to be DRB1*11 $11^{+}$. Vaccine-induced DTH and IFN $\gamma$ responses, were augmented in the vast majority of DRB1*11+ patients. No correlation was observed between the pre-existing levels of serum TGF $\beta$ and the expression of the DRB1*11 allele. With a median follow up of 71 months, Kaplan-Meir analyses demonstrated a $22 \%$ and $72 \%$ relative reduction in recurrence rate (RRR) in DRB1* $11^{+}$patients and those with pre-existent immunity, respectively. Overall survival analysis of DRB1* $11^{+}$patients showed a $50 \%$ relative reduction in death rate (RRD), and a 74\% RRD in patients with pre-existent immunity.

\section{Conclusions}

Our data demonstrate both immunologic and clinical advantage of vaccination therapy with AE37 among patients expressing DRB1*11 and/or having pre-existing HER2 immunity, highlighting their potential roles as 
predictive biomarkers to select patients most likely to benefit from vaccination with AE37.

\section{Trial Registration}

ClinicalTrials.gov identifier NCT00524277.

\section{Authors' details}

${ }^{1}$ Cancer Immunology and Immunotherapy Center, Saint Savas Cancer Hospital, Athens, Greece. ${ }^{2}$ St Savas Cancer Hospital, 1st Medical Oncology Clinic, Athens, Greece. ${ }^{3}$ The University of Texas MD Anderson Cancer Center, Houston, TX, USA. ${ }^{4}$ Cancer Vaccine Development Program, San Antonio, TX, USA.

Published: 4 November 2015

doi:10.1186/2051-1426-3-S2-P427

Cite this article as: Anastasopoulou et al:: DRB1*11 allele expression and HER2 pre-existing immunity may predict benefit in breast cancer patients vaccinated with the HER2 modified AE37 peptide vaccine. Journal for Immunotherapy of Cancer 2015 3(Suppl 2):P427.

Submit your next manuscript to BioMed Central and take full advantage of:

- Convenient online submission

- Thorough peer review

- No space constraints or color figure charges

- Immediate publication on acceptance

- Inclusion in PubMed, CAS, Scopus and Google Scholar

- Research which is freely available for redistribution

Submit your manuscript at www.biomedcentral.com/submit 